\title{
GENETIC IMPROVEMENT FOR WOOD PRODUCTION IN MELALEUCA CAJUPUTI
}

\author{
Nguyen THH ${ }^{1,2}$, Konda $\mathbf{R}^{3}$, Kieu TD ${ }^{2}$, Tran TC $^{2}$, Phung VK ${ }^{2}$, Tran TH $^{3} \&$ Wu HX ${ }^{1,4, *}$ \\ ${ }^{1}$ Swedish University of Agricultural Science, Department of Forest Genetics and Plant Physiology, Linnaeus väg 6, \\ SE-901 83 Umeå, Sweden \\ ${ }^{2}$ Forest Science Institute of South Vietnam, No. 1 Pham Van Hai, Tan Binh District, Ho Chi Minh City, Vietnam \\ ${ }^{3}$ Tsukuba Research Institute-Sumitomo Forestry Co. Ltd., No. 3-2, Midorigahara, Tsukuba-shi, Ibaraki, 300-2646 Japan \\ ${ }^{4}$ Beijing Advanced Innovation Centre for Tree Breeding by Molecular Design, Beijing Forestry University, Beijing, 100083 \\ China
}

*Harry.wu@slu.se

Submitted May 2018; accepted January 2019

\begin{abstract}
Genetic parameters was estimated for growth (tree height, diameter at breast height (DBH) and volume), stem form, MOE (wood stiffness), bark thickness and bark ratio in a half-sib family progeny trial of Melaleuca cajuputi comprising 80 families in South Vietnam. MOE of standing trees was measured indirectly by acoustic velocity using microsecond timer. Narrow-sense heritability ranged from 0.13 to 0.27 at age 7 years. MOE and stem form had positive genetic correlations with growth while negative correlation between bark ratio and growth was also favourable. Breeding for simultaneous improvement of multiple traits, faster growth with higher MOE and reduction of bark ratio should be possible in M. cajuputi. Index selection based on volume and MOE showed genetic gains of $31 \%$ in volume, $6 \%$ in MOE and $13 \%$ in stem form. In addition, heritability and age-age genetic correlations for growth traits increased with time and optimal early selection age for growth of $M$. cajuputi based on DBH alone was 4 years. Selected thinning resulted in an increase in heritability due to considerable reduction of phenotypic variation but had little effect on genetic variation.
\end{abstract}

Keywords: Heritability, age-age correlation, stiffness, acoustic velocity, bark thickness, optimum selection age, thinning effect

\section{INTRODUCTION}

Melaleuca cajuputi is a moderately fast-growing tree species considered to be a multipurpose species supplying fuelwood, piles and frame poles of construction, leaf essential oil and honey (Doran \& Turnbull 1997). The species includes three recognised subspecies: cajuputi, cumingiana and platyphylla, which occur in Australia, Papua New Guinea and South-EastAsia (Craven \& Barlow 1997, Brophy et al. 2013). Melaleuca cajuputi plantation can be harvested on 6-7-year rotations (Trung 2008, Nuyim 2001). Its timber can be used for pulp and paper, fibre and particle board, producing quality charcoal and potentially sawn timber (Trung 2008). The species is adapted to tropical environments and particularly to soils with higher salinities and/or aluminum levels as well as being tolerant to fire, drought, flooding and low soil pH (Yamanoshita et al. 1999, Nuyim 2001, Tran et al. 2013). It is well suited to sites in the Mekong Delta in Vietnam that are otherwise difficult for tree plantation establishment due to seasonal inundation and acid sulfate soils (Chuong et al. 1996, Doran \& Turnbull 1997).

Species/provenance trials of melaleucas for wood and/or essential oil production were established in 1993 in the Mekong Delta (Kha et al. 1999). One of the species included in these trials, M. cajuputi subsp. cumingiana which is indigenous to Vietnam (Craven \& Barlow 1997), was selected as a top priority for reforestation efforts in Mekong Delta, even though it was outperformed in growth by some exotic Melaleuca species introduced from Australia and Papua New Guinea (Kha et al. 1999, Pinypusarerk \& Doran 1999). Three natural provenances of $M$. cajuputi subsp. cumingiana (Moc Hoa, Vinh Hung and Tinh Bien) were recognised by the Vietnamese Ministry of Agriculture and Rural Development as advanced varieties for commercial plantation establishment. 
A breeding programme for $M$. cajuputi that aims primarily at improving yields of essential leaf oils has been conducted for many years in Indonesia (Doran et al. 1998). Genetic gains of 10 and $21 \%$ for the content of 1.8 cineole and oil yield respectively have been reported (Susanto et al. 2003). Genetic variation, mating system, fertility variation and genetic diversity of M. cajuputi were also studied (Kartikawati et al. 2013, Kartikawati 2016). Most M. cajuputi breeding programmes have been focused on oil production. After recognition of the potential of this species for wood production in acid sulfate soils of the Mekong Delta, a breeding programme aimed at improving tree growth for wood production was established in Vietnam in 2006. Preliminary works had been done to examine mechanical properties and anatomical characteristics of M. cajuputi timber (Junji 1999, Ban 2002). However, basic information about genetic variation in wood properties of $M$. cajuputi has not been reported.

This study was conducted to evaluate genetic variation in growth, stem form, MOE, bark thickness and bark ratio in an open-pollinated progeny trial of 7-year-old M. cajuputi in southern Vietnam. Estimates of heritability, genetic and phenotypic correlations between the traits are presented. The expected response from combined index selection, based on genetic parameters for growth and wood stiffness, i.e. modulus of elasticity (MOE) is discussed in relation to the breeding strategy to improve wood production.

\section{MATERIALS AND METHODS}

\section{Trial site, genetic material and experimental design}

An open-pollinated progeny trial of M. cajuputi subsp. cumingiana was established in July 2009 at Thanh Hoa, Long An province $\left(10^{\circ} 35^{\prime} \mathrm{N}\right.$, $106^{\circ} 11^{\prime} \mathrm{E}, 12 \mathrm{~m}$ above sea level) on seasonally inundated acid sulphate soil ( $\mathrm{pH}$ 2.9-3.7). Average temperature is $27.3{ }^{\circ} \mathrm{C}$ and annual rainfall ranges from 1325 to $1670 \mathrm{~mm}$. Rainy season starts from May and ends in November. About $93 \%$ of total annual rainfall occurs in the rainy seasons. Inundation of the local area usually begins in the middle of August and lasts till November. Maximum water level can reach above $1.5 \mathrm{~m}$.
The trial comprised 80 families collected from individual plus trees with fast growth, good stem form (straightness and narrow crown), fruiting and no visible insect or disease damage. All plus trees were selected in three natural provenance locations, namely, Moc Hoa, Vinh Hung and Tinh Bien in the Mekong Delta. The trial was planted as randomised complete block design and represented by 51 replicates. Each replicate consisted of a 4-tree row plot of each family, with a spacing of $1 \mathrm{~m}$ between trees within rows and $1.5 \mathrm{~m}$ between rows. The entire trial was thinned at age 4 years to retain the best two trees in each family plot. Felled trees were either dead or had other deficiencies (slow growth, broken stems or attacked by stem borer).

\section{Data collection and analysis}

Eighteen replicates in the trial were assessed for diameter at breast height (DBH) and total height from 2010 to 2016. Volume, stem form, bark thickness, bark ratio and acoustic velocity were evaluated in 2016, and MOE was computed using acoustic velocity. DBH and tree height $(\mathrm{H})$ were measured using tapeline and measurement pole. Stem volume $(\mathrm{V})$ was calculated by the formula:

$$
\mathrm{V}\left(\mathrm{dm}^{3}\right)=\frac{\pi \mathrm{DBH}^{2}}{4} \times \mathrm{H} \times \mathrm{f}
$$

where, $\mathrm{f}$ is a form index and was estimated to be 0.5 (Kha et al. 1999).

Bark thickness was measured at three points around $1.3 \mathrm{~m}$ height of the stem using nail and callipers. Bark ratio was calculated by volume basis (bark volume/under-bark stem volume). Tree form was scored as one of four categories based on construction pole requirements, i.e. $1=$ bad, $2=$ average, $3=$ good and $4=$ very good. A non-destructive testing method was used for computing MOE using acoustic velocity on standing tree (Jayawickrama 2001). Two probes were inserted into a tree stem, $1 \mathrm{~m}$ apart, between 0.7 and $1.7 \mathrm{~m}$ and three horizontal points on the same stem (e.g. $120^{\circ}$ between each point) were measured. The acoustic velocity (AV) were calculated using the equation:

$$
\mathrm{AV}\left(\mathrm{ms}^{-1}\right)=\frac{\mathrm{s}}{\mathrm{t}}
$$

where, $\mathrm{s}$ is the distance between probes and $\mathrm{t}$ is the transit time. MOE was estimated from the 
acoustic velocity through the one-dimensional wave equation (Johnson \& Gartner 2006):

$$
\operatorname{MOE}(\mathrm{GPa})=\mathrm{AV}^{2} \rho
$$

where, $\rho$ is green density of the material $\left(\mathrm{kg} \mathrm{m}^{-3}\right)$. Seven-year-old M. cajuputi green density $\left(968 \mathrm{~kg} \mathrm{~m}^{-3}\right)$ was assumed to be constant.

Variance and covariance components for all phenotypic traits were estimated by mixed-model equation (Isik et al. 2017):

$$
\mathrm{Y}_{\mathrm{ijk}}=\mu+\mathrm{B}_{\mathrm{i}}+\mathrm{P}_{\mathrm{j}}+\mathrm{F}_{\mathrm{k}(\mathrm{j})}+\mathrm{BF}_{\mathrm{k}}+\mathrm{e}_{\mathrm{ijk}}
$$

where, $Y_{i j k}$ is the plot mean of $k^{\text {th }}$ family within provenance $j^{\text {th }}$ within replicate $i^{\text {th }} ; \mu$ is the overall mean; $B_{i}, P_{j}$ and $F_{k(j)}$ are the effects of $i^{\text {th }}$ block (or replicate), $\mathrm{j}^{\text {th }}$ provenance and $\mathrm{k}^{\text {th }}$ family effect; $\mathrm{BF}_{\mathrm{ik}}$ is the random family by block interaction effect; and $\mathrm{e}_{\mathrm{ijk}}$ is the residual error with a mean of zero. For these analyses, provenances were regarded as fixed effects while families, block and family by block interaction were regarded as random.

For each trait, the narrow-sense heritability $\left(\mathrm{h}_{\mathrm{i}}^{2}\right)$, family mean heritability $\left(\mathrm{h}_{\mathrm{fm}}^{2}\right)$ and within family heritability $\left(\mathrm{h}_{\mathrm{w}}^{2}\right)$ were estimated from univariate analyses as follows:

$$
\begin{aligned}
& \mathrm{h}_{\mathrm{i}}^{2}=\frac{\sigma_{\mathrm{A}}^{2}}{\sigma_{\mathrm{p}}^{2}}=\frac{4 \sigma_{\mathrm{f}}^{2}}{\sigma_{\mathrm{p}}^{2}}\left(\sigma_{\mathrm{p}}^{2}=\sigma_{\mathrm{f}}^{2}+\sigma_{\mathrm{bf}}^{2}+\sigma_{\mathrm{e}}^{2}\right) \\
& \mathrm{h}_{\mathrm{fm}}^{2}=\frac{\sigma_{\mathrm{f}}^{2}}{\sigma_{\mathrm{fm}}^{2}}\left(\sigma_{\mathrm{fm}}^{2}=\sigma_{\mathrm{f}}^{2}+\frac{1}{\mathrm{~b}} \sigma_{\mathrm{bf}}^{2}+\frac{1}{\mathrm{bn}} \sigma_{\mathrm{e}}^{2}\right) \\
& \mathrm{h}_{\mathrm{w}}^{2}=\frac{3 \sigma_{\mathrm{f}}^{2}}{\sigma_{\mathrm{w}}^{2}}\left(\sigma_{\mathrm{w}}^{2}=\frac{(\mathrm{b}-1)}{\mathrm{b}} \sigma_{\mathrm{bf}}^{2}+\frac{(\mathrm{bn}-1)}{\mathrm{bn}} \sigma_{\mathrm{e}}^{2}\right)
\end{aligned}
$$

where, $\sigma_{\mathrm{A}}^{2}$ and $\sigma_{\mathrm{p}}^{2}$ are the additive and phenotypic variances; $\sigma_{\mathrm{f}}^{2}$ and $\sigma_{\mathrm{e}}^{2}$ are the family and residual variances; $\sigma_{\mathrm{bf}}^{2}$ is the variance of family by block interaction; $\sigma_{\text {fm }}^{2}$ and $\sigma_{\mathrm{w}}^{2}$ are the family mean and within family variances; and $\mathrm{b}$ and $\mathrm{n}$ are number of blocks and plants per block respectively. Coefficients of variation $(\mathrm{CV})$ was calculated as:

$$
\mathrm{CV}_{1}=\frac{100 \sqrt{\sigma_{1}^{2}}}{\overline{\mathrm{X}}}
$$

where, $\sigma_{1}^{2}$ is the considered variance and $\overline{\mathrm{X}}$ is the phenotypic mean of the trait.

Genetic $\left(r_{g}\right)$ and phenotypic $\left(r_{p}\right)$ correlations between traits were calculated as:

$$
\begin{aligned}
& r_{g}=\frac{\operatorname{Cov}_{f(x, y)}}{\left[\sigma_{f}^{2}(x) \cdot \sigma_{f}^{2}(y)\right]^{1 / 2}} \\
& r_{p}=\frac{\operatorname{Cov}_{p(x, y)}}{\left[\sigma_{p}^{2}(x) \cdot \sigma_{p}^{2}(y)\right]^{1 / 2}}
\end{aligned}
$$

where, $\operatorname{Cov}_{\mathrm{f}}(\mathrm{x}, \mathrm{y})$ and $\operatorname{Cov}_{\mathrm{p}}(\mathrm{x}, \mathrm{y})$ are family covariance component and phenotypic covariance (based on family means) between traits $\mathrm{x}$ and y respectively; and $\sigma_{\mathrm{f}}^{2}(\mathrm{x}) \sigma_{\mathrm{f}}^{2}(\mathrm{y})$ and are family level variance components of trait $\mathrm{x}$ and $y$. Expected genetic gain $(\Delta G)$ is the amount of increase in performance from mass selection in the trial and estimated by the formula:

$$
\Delta \mathrm{G}=\mathrm{h}_{\mathrm{i}}^{2} \times \mathrm{i} \times \sigma_{\mathrm{p}}
$$

where, $\mathrm{i}$ is selection intensity, $\sigma_{\mathrm{p}}$ is the phenotypic standard deviation for the trait of interest and $\mathrm{h}_{\mathrm{i}}{ }^{2}$ is individual tree heritability for the trait of interest. The correlated responses were calculated as:

$$
\mathrm{CR}_{\mathrm{Y}}=\mathrm{ih}_{\mathrm{X}} \mathrm{h}_{\mathrm{Y}} \mathrm{r}_{\mathrm{g}} \sigma_{\mathrm{PY}}
$$

where, character $\mathrm{X}$ is selected directly and then $\mathrm{Y}$ is a correlated character selected indirectly. Breeding selection was based on selection indices (I) constructed for improvement of single and multiple traits and with or without restriction among traits (Falconer \& Mackay 1996).

$$
\mathrm{I}=\mathrm{b}_{1} \mathrm{P}_{1}+\mathrm{b}_{2} \mathrm{P}_{2}+\ldots+\mathrm{b}_{\mathrm{m}} \mathrm{P}_{\mathrm{m}}
$$

where $P_{1}$ to $P_{m}$ are phenotypic measurements of $\mathrm{m}$ characters on which selection is to be based, and $b_{1}$ to $b_{m}$ are the corresponding weighting factors to be determined. A total of six different selection scenarios were considered:

A-selection for each independent trait, B-selection based on DBH, but calculating indirect effect on other correlated traits, $\mathrm{C}$-selection based on volume, but calculating indirect effect on other correlated traits, D-index selection based on volume and stem form,

$\mathrm{E}$-index selection based on volume and MOE, and

F-index selection based on volume and MOE with the restriction of no change on bark thickness. 
The index coefficients were obtained from

$$
\mathrm{b}=\mathrm{P}^{-1} \times \mathrm{G} \times \mathrm{a}
$$

where $\mathrm{P}$ and $\mathrm{G}$ are the phenotypic and additive genetic variance-covariance matrices for selected traits, and a is vector of weighting coefficients assigned as reciprocals of the phenotypic standard deviations for each of objective traits (equal economic values are assigned to one standard deviation for change in each character). For restricted selection index, equation 14 could be modified as (Mrode \& Thompson 2005):

$$
b^{*}=\left[\begin{array}{cc}
P^{*} & G^{*} \\
G^{*} & 0
\end{array}\right]^{-1} \times\left[\begin{array}{l}
G^{* *} \\
0
\end{array}\right] \times a
$$

where $\mathrm{P}^{*}$ is the phenotypic variance-covariance matrix for selection traits; $G^{*}$ is the additive genetic variance-covariance matrix between selected traits and traits excluding restricted traits; $G^{* *}$ is the additive genetic variancecovariance matrix between selected traits excluding restricted traits; and 0 is the zero vector. Statistical analyses were conducted using ASReml 4.0 (2014).

\section{RESULTS}

\section{Mean, variation and heritability}

Mean values, ranges, standard deviations and coefficients of variation of $\mathrm{DBH}$, height, volume, stem form, acoustic velocity, MOE, bark ratio and thickness traits at 7 years are presented in Table 1. Acoustic velocity showed the smallest phenotypic variation $(6.30 \%)$, followed by tree height, MOE and DBH (between 12.17-20.19\%), while bark ratio, bark thickness and stem form showed large phenotypic variation (24.29-32.26\%) and the largest phenotypic variation was volume $(50.14 \%)$.

Individual heritability ranged from 0.13 to 0.27 while family mean heritability for these traits was higher (0.49-0.64) than both the individual heritability and the within family heritability (0.11-0.22) (Table 2). Individual heritability estimates for growth (DBH, height and volume) were in a narrow range of $0.25-0.27$. Stem form had the lowest heritability (0.13), while MOE and acoustic velocity had moderate heritability of 0.21 and bark thickness and ratio had 0.23 and 0.21 respectively.

\section{Phenotypic and genetic correlations between traits}

The phenotypic and genetic correlations between DBH, height, volume, stem form, acoustic velocity, MOE, bark thickness and bark ratio for $M$. cajuputi at 7 years are shown in Table 3 . There were very strong genetic $\left(r_{\mathrm{g}}=0.88\right.$ to 0.99$)$ and phenotypic $\left(r_{p}=0.73\right.$ to 0.97$)$ correlations between growth traits. MOE had positive genetic and phenotypic correlations with growth, stem form and bark thickness. The genetic correlations between MOE and growth were moderate, i.e. 0.33-0.50. Negative correlations were found between bark ratio and growth traits

Table 1 Mean, range (minimum and maximum), standard deviation (SD) and coefficient of variation (CV) for growth, stem form, acoustic velocity, MOE, bark ratio and thickness of 7-year-old Melaleuca cajuputi in the progeny trial at Thanh Hoa, Long An, Vietnam

\begin{tabular}{lccccc}
\hline Trait & Mean & Minimum & Maximum & SD & CV $(\%)$ \\
\hline DBH $(\mathrm{cm})$ & 7.77 & 3.20 & 14.60 & 1.57 & 20.19 \\
Tree height $(\mathrm{m})$ & 8.64 & 4.10 & 12.90 & 1.05 & 12.17 \\
Volume $\left(\mathrm{dm}^{3}\right)$ & 22.08 & 1.65 & 108.00 & 11.07 & 50.14 \\
Stem form & 2.64 & 1.00 & 4.00 & 0.85 & 32.26 \\
Acoustic velocity $\left(\mathrm{km} \mathrm{s}^{-1}\right)$ & 3.65 & 2.63 & 4.35 & 0.23 & 6.30 \\
MOE $(\mathrm{GPa})$ & 12.94 & 6.69 & 18.33 & 1.61 & 12.44 \\
Bark ratio $(\%)$ & 50.72 & 16.80 & 100.20 & 1.32 & 24.29 \\
Bark thickness $(\mathrm{cm})$ & 0.68 & 0.21 & & 0.17 & 25.25 \\
\hline
\end{tabular}

$\mathrm{DBH}=$ diameter at breast height, $\mathrm{MOE}=$ modulus of elasticity 
Table 2 Estimated individual $\left(\mathrm{h}_{\mathrm{i}}^{2}\right)$, family mean $\left(\mathrm{h}^{2}{ }_{\mathrm{fm}}\right)$ and within family $\left(\mathrm{h}^{2}{ }_{\mathrm{w}}\right)$ heritability values of 7-year-old M. cajuputi

\begin{tabular}{lccc}
\hline Trait & $\mathrm{h}^{2}{ }_{\mathrm{i}}$ & $\mathrm{h}^{2}{ }_{\mathrm{fm}}$ & $\mathrm{h}^{2}{ }_{\mathrm{w}}$ \\
\hline DBH & $0.25(0.06)$ & $0.64(0.06)$ & $0.21(0.05)$ \\
Height & $0.27(0.07)$ & $0.62(0.06)$ & $0.22(0.06)$ \\
Volume & $0.26(0.06)$ & $0.64(0.06)$ & $0.21(0.05)$ \\
Stem form & $0.13(0.04)$ & $0.49(0.09)$ & $0.11(0.04)$ \\
Acoustic velocity & $0.21(0.06)$ & $0.59(0.07)$ & $0.18(0.05)$ \\
MOE & $0.21(0.06)$ & $0.60(0.07)$ & $0.18(0.05)$ \\
Bark ratio & $0.23(0.06)$ & $0.59(0.07)$ & $0.19(0.05)$ \\
Bark thickness & $0.21(0.06)$ & $0.58(0.07)$ & $0.18(0.05)$ \\
\hline
\end{tabular}

$\mathrm{DBH}=$ diameter at breast height, $\mathrm{MOE}=$ modulus of elasticity; standard errors are given in parentheses

Table 3 Genetic (above the diagonal) and phenotypic (below the diagonal) correlation between traits of 7-year-old M. cajuputi progeny trial

\begin{tabular}{lcccccccc}
\hline Trait & DBH & Height & Volume & $\begin{array}{c}\text { Stem } \\
\text { form }\end{array}$ & $\begin{array}{c}\text { Acoustic } \\
\text { velocity }\end{array}$ & MOE & Bark ratio & Bark thickness \\
\hline DBH & & 0.88 & 0.99 & 0.76 & 0.33 & 0.33 & -0.22 & 0.76 \\
& & $(0.04)$ & $(0.01)$ & $(0.09)$ & $(0.16)$ & $(0.16)$ & $(0.16)$ & $(0.07)$ \\
Height & 0.73 & & 0.92 & 0.88 & 0.50 & 0.50 & -0.34 & 0.57 \\
& $(0.01)$ & & $(0.03)$ & $(0.07)$ & $(0.13)$ & $(0.13)$ & $(0.15)$ & $(0.11)$ \\
Volume & 0.97 & 0.79 & & 0.76 & 0.36 & 0.36 & -0.23 & 0.73 \\
& $(0.00)$ & $(0.01)$ & & $(0.09)$ & $(0.15)$ & $(0.15)$ & $(0.16)$ & $(0.08)$ \\
Stem form & 0.60 & 0.63 & 0.56 & & 0.49 & 0.49 & -0.23 & 0.56 \\
& $(0.01)$ & $(0.01)$ & $(0.01)$ & & $(0.16)$ & $(0.16)$ & $(0.18)$ & $(0.14)$ \\
Acoustic velocity & 0.14 & 0.39 & 0.16 & 0.28 & & 1.00 & 0.03 & 0.34 \\
& $(0.02)$ & $(0.02)$ & $(0.02)$ & $(0.02)$ & & $(0.00)$ & $(0.17)$ & $(0.16)$ \\
MOE & 0.14 & 0.39 & 0.16 & 0.27 & 1.00 & & 0.02 & 0.34 \\
& $(0.02)$ & $(0.02)$ & $(0.02)$ & $(0.02)$ & $(0.00)$ & & $(0.17)$ & $(0.16)$ \\
Bark ratio & -0.13 & -0.19 & -0.12 & -0.15 & -0.09 & -0.09 & & 0.47 \\
& $(0.02)$ & $(0.02)$ & $(0.02)$ & $(0.02)$ & $(0.02)$ & $(0.02)$ & & $(0.13)$ \\
Bark thickness & 0.73 & 0.49 & 0.70 & 0.40 & 0.07 & 0.07 & 0.54 & $(0.02)$ \\
& $(0.01)$ & $(0.02)$ & $(0.01)$ & $(0.02)$ & $(0.02)$ & $(0.02)$ &
\end{tabular}

$\mathrm{DBH}=$ diameter at breast height, $\mathrm{MOE}=$ modulus of elasticity; standard errors are given in parentheses

as well as between bark ratio and stem form. Bark ratio had moderate positive correlation with bark thickness. The correlation between bark ratio and MOE was nearly zero.

Trends of growth and heritability, and the effect of thinning

The age trends for growth and heritability for $\mathrm{DBH}$ and height are shown in Figure 1. The heritability for height increased from age 1 to
7. Heritability for DBH and height increased considerably after thinning at age 4 . The highest values of heritability for growth were reached at 7 years. Selective thinning of $50 \%$ of trees resulted in reduction of phenotypic coefficient of variation of DBH and height (Figure 2).

The correlations between DBH and height from age 1 to 7 were moderate to strong and ranged from 0.45 to 0.99 (Figure 3 ). The phenotypic correlations were weaker than genetic correlations between $\mathrm{DBH}$ and height 


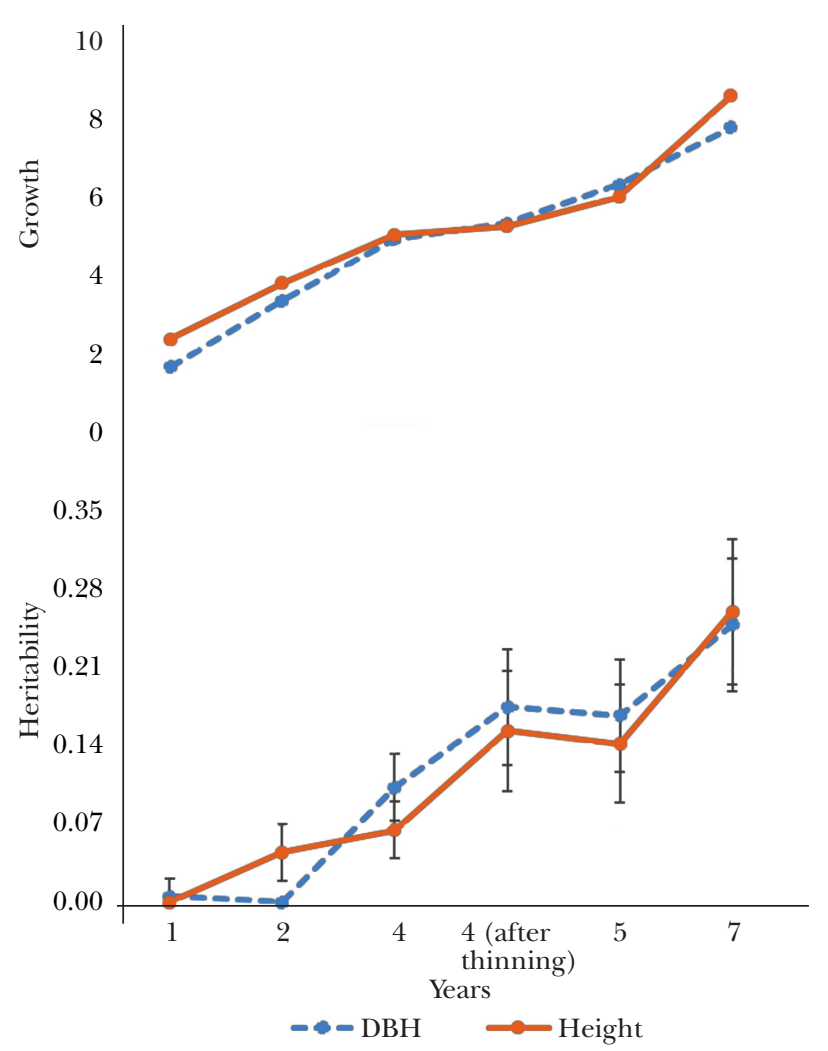

Figure 1 Diameter at breast height $(\mathrm{DBH})(\mathrm{cm})$ and height $(\mathrm{m})$ growth and heritability for Melaleuca cajuputi from ages 1 to 7 years old

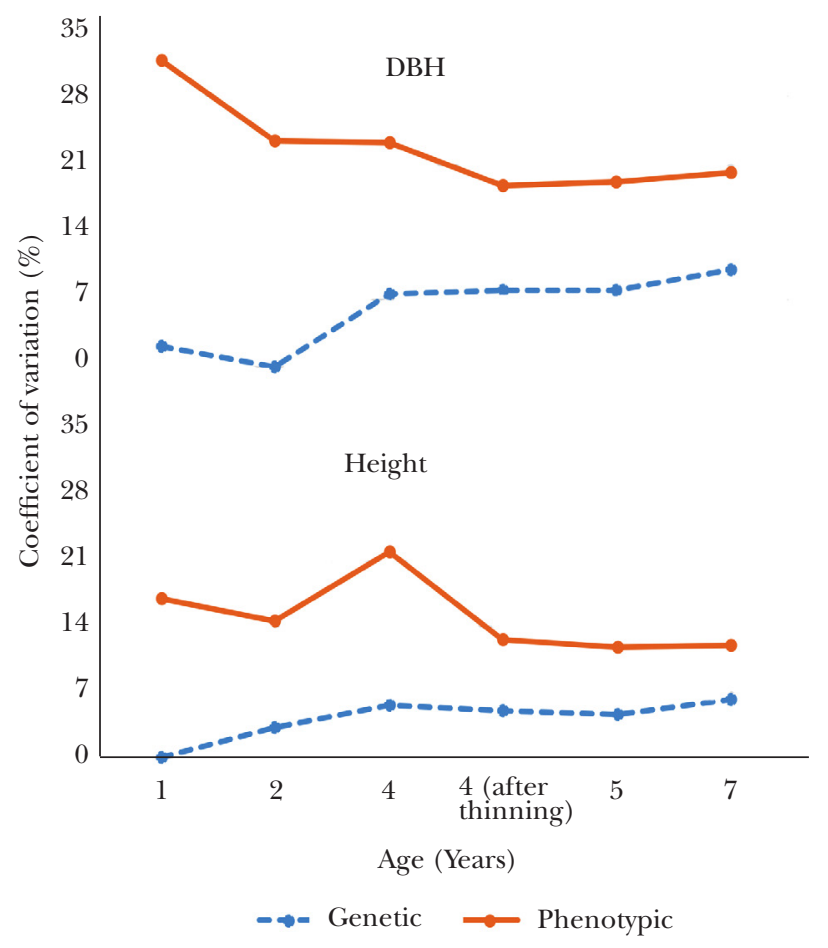

Figure 2 Genetic and phenotypic coefficient of variation trend for $\mathrm{DBH}$ and height for Melaleuca cajuputi from ages 1 to 7 years old

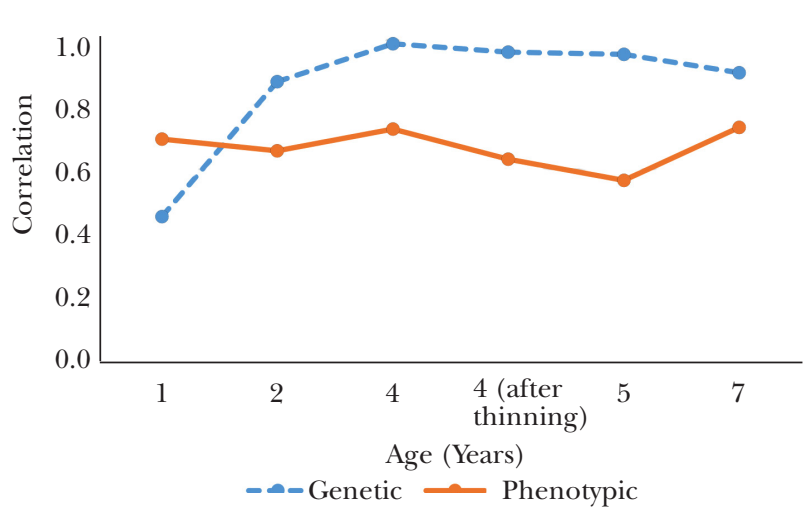

Figure 3 Genetic and phenotypic correlations between DBH and height for Melaleuca cajuputi from age 1 to 7 years old

at all ages except for age 1 . Genetic correlations increased sharply from age 1 to 2 , moderate from age 2 to 4 and decreased slightly after age 4. However, strong genetic correlations between $\mathrm{DBH}$ and height started from age 2.

\section{Age-age correlation}

Age-age correlations from age 1 to 7 years are shown in Figure 4. The age-age genetic correlation values were weak to moderate between ages 7 and 1 and ages 7 and 2 but stronger between ages 7 and 4 (both before and after thinning), and ages 7 and 5. For DBH and height, the trend of age-age correlation increased sharply from ages 2 to 4 and was nearly constant thereafter. DBH had higher age-age correlations than height after age 2.

\section{Response for different selection scenarios}

The results of six different selection scenarios are presented in Table 4 with the same selection intensity of 2.67 (i.e. 1\%). In scenario A, genetic gains reached 7 to $34 \%$ as selection was based on each independent trait. Selections based on DBH alone (scenario B), volume (scenario C), volume and form (scenario D) showed negligible differences of genetic gains for growth traits. Genetic gains reached about $33 \%$ for volume, $9-13 \%$ for stem form and $1-4 \%$ for MOE. However, selection based on volume and MOE (scenario E) had less genetic gain of volume (31\%, relative to $33 \%$ ) but considerable increase in MOE $(6 \%)$ compared with scenarios B, C and $\mathrm{D}$. There were considerable differences in expected responses between selection based 


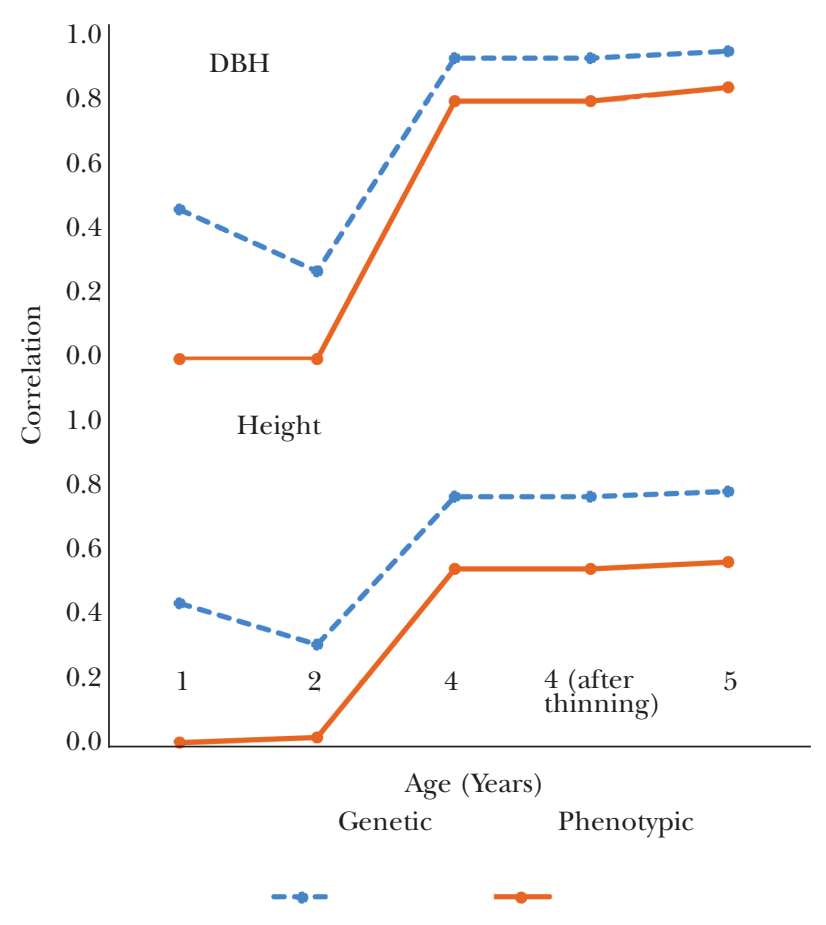

Figure 4 Genetic and phenotypic correlations for DBH and height of Melaleuca cajuputi between age 7 and earlier ages

on volume and MOE with the restriction of no change on bark thickness (scenario F) and all other scenarios. Restriction of no change on bark thickness in breeding selection resulted in decreasing expected responses of $16 \%$ in volume, $7 \%$ in stem form and $5 \%$ in MOE.

\section{DISCUSSION}

\section{Mean, variation and heritability}

The growth of 7-year-old $M$. cajuputi in this study reached $7.77 \mathrm{~cm}$ in DBH, $8.64 \mathrm{~m}$ in height and $22.08 \mathrm{dm}^{3}$ in volume. This result was similar to the previous studies in Vietnam (Hong et al. 2010). The phenotypic variations of growth traits were also close to the results of Melaleuca species/ provenance trial $(25.8 \%$ in DBH, $12.0 \%$ in height and $58.8 \%$ in volume) at the same age in Mekong Delta (Hong et al. 2010).

One of the main wood properties of interest to the wood industry is MOE. Acoustic tools have been used to measure MOE of standing trees, stems and logs (Jayawickrama 2001, Grabianowski et al. 2006). Previous studies of mechanical properties of Melaleuca wood used destructive methods (Junji 1999, Ban 2002, Wahyudi et al. 2014). In this study, non-destructive evaluation of mechanical properties of wood was conducted. The average MOE of M. cajuputi was $12.94 \mathrm{GPa}$ at age 7 years, higher than the results reported by Ban (2002) on some wood characteristics of $M$. cajuputi at 6 years old $(10.69 \mathrm{GPa})$ and $M$. viridiflora $(11.38 \mathrm{GPa})$ but lower than M. leucadendra (13.83 GPa) at the same age. From these results, it seems that the larger the diameter, the higher the MOE of M. cajuputi. Melaleuca cajuputi showed lower acoustic velocity than Eucalyptus globulus at 10 years (Hamilton et al. 2017), but close to E. nitens at 14-19 years (Blackburn et al. 2014) and Acacia melanoxoxylon at 18 years old (Bradbury et al. 2011). Generally, Melaleuca wood has strong properties and high possibility to be used as a structural component (Junji 1999).

The heritability for MOE of M. cajuputi was moderate $\left(\mathrm{h}_{\mathrm{i}}^{2}=0.21\right)$ and lower compared with the estimates of 10-year-old E. globulus (0.26) (Hamilton et al. 2017) and 8-year-old E. urophylla (0.47) (Wu et al. 2013) but higher than 24-yearold Norway spruce $\left(\mathrm{h}_{\mathrm{i}}^{2}=0.15\right) \quad($ Chen et al. 2015). Eucalyptus nitens had a large range of heritability (0.16-0.74) at different sites (Blackburn et al. 2014). The bark of M. cajuputi species is very thick and the bark to under-bark stem volume ratio can reach $100 \%$. Bark thickness and its percentage of volume of the tree or log are important in forest inventory and has a major effect on the amount of usable wood (Kleinn 2007). According to Van et al. (2000), variations in Melaleuca bark thickness were large at different sites in southern Florida. The percentage of bark fluctuates depending on species and size of tree which varies from $8 \%$ in volume for some large hardwood species to $40 \%$ for small tropical pines (Zobel \& Jett 1995). In this study, M. cajuputi had high bark ratio of $50.72 \%$. It was considerately higher than those of Eucalyptus grandis (7.43\%) and E. urophylla (17.31\%) (Retief \& Stanger 2009). Thus, actual wood volume will be overestimated when tree diameter over bark is measured.

\section{Phenotypic and genetic correlations between traits}

The phenotypic and genetic correlations between all traits except for bark ratio of M. cajuputi were positive. This suggests that selection for one of these traits should result in a simultaneous positive response in other traits. The results of this study are comparable with different studies 
Table 4 Expected response for DBH, height, volume, stem form, MOE, bark ratio and bark thickness of Melaleuca cajuputi when different selection criteria were used under selection intensity of $1 \%$ $(\mathrm{i}=2.67)$

\begin{tabular}{|c|c|c|c|c|c|c|c|}
\hline Scenario & $\begin{array}{l}\mathrm{DBH} \\
(\mathrm{cm})\end{array}$ & $\begin{array}{l}\text { Tree height } \\
(\mathrm{m})\end{array}$ & $\begin{array}{l}\text { Volume } \\
\left(\mathrm{dm}^{3}\right)\end{array}$ & Stem form & $\begin{array}{l}\mathrm{MOE} \\
(\mathrm{GPa})\end{array}$ & $\begin{array}{c}\text { Bark ratio } \\
(\%)\end{array}$ & $\begin{array}{c}\text { Bark thickness } \\
(\mathrm{cm})\end{array}$ \\
\hline A & $\begin{array}{c}1.05 \\
(13.51 \%)\end{array}$ & $\begin{array}{c}0.72 \\
(8.33 \%)\end{array}$ & $\begin{array}{c}7.50 \\
(33.97 \%)\end{array}$ & $\begin{array}{c}0.30 \\
(11.50 \%)\end{array}$ & $\begin{array}{c}0.09 \\
(6.92 \%)\end{array}$ & $\begin{array}{c}6.71 \\
(13.24 \%)\end{array}$ & $\begin{array}{c}0.10 \\
(14.05 \%)\end{array}$ \\
\hline B & $\begin{array}{c}1.05 \\
(13.51 \%)\end{array}$ & $\begin{array}{c}0.62 \\
(7.19 \%)\end{array}$ & $\begin{array}{c}7.35 \\
(33.27 \%)\end{array}$ & $\begin{array}{c}0.32 \\
(11.96 \%)\end{array}$ & $\begin{array}{c}0.47 \\
(3.66 \%)\end{array}$ & $\begin{array}{c}-1.54 \\
(-3.03 \%)\end{array}$ & $\begin{array}{c}0.08 \\
(11.51 \%)\end{array}$ \\
\hline $\mathrm{C}$ & $\begin{array}{c}1.05 \\
(13.47 \%)\end{array}$ & $\begin{array}{c}0.66 \\
(7.59 \%)\end{array}$ & $\begin{array}{c}7.50 \\
(33.97 \%)\end{array}$ & $\begin{array}{c}0.24 \\
(8.94 \%)\end{array}$ & $\begin{array}{c}0.15 \\
(1.16 \%)\end{array}$ & $\begin{array}{c}-0.86 \\
(-1.69 \%)\end{array}$ & $\begin{array}{c}0.07 \\
(10.81 \%)\end{array}$ \\
\hline $\mathrm{D}$ & $\begin{array}{c}1.03 \\
(13.30 \%)\end{array}$ & $\begin{array}{c}0.66 \\
(7.71 \%)\end{array}$ & $\begin{array}{c}7.39 \\
(33.48 \%)\end{array}$ & $\begin{array}{c}0.34 \\
(12.84 \%)\end{array}$ & $\begin{array}{c}0.37 \\
(2.86 \%)\end{array}$ & $\begin{array}{c}-1.64 \\
(-3.24 \%)\end{array}$ & $\begin{array}{c}0.08 \\
(11.16 \%)\end{array}$ \\
\hline $\mathrm{E}$ & $\begin{array}{c}0.93 \\
(11.96 \%)\end{array}$ & $\begin{array}{c}0.66 \\
(7.66 \%)\end{array}$ & $\begin{array}{c}6.80 \\
(30.81 \%)\end{array}$ & $\begin{array}{c}0.34 \\
(12.87 \%)\end{array}$ & $\begin{array}{c}0.79 \\
(6.09 \%)\end{array}$ & $\begin{array}{c}-1.01 \\
(-1.99 \%)\end{array}$ & $\begin{array}{c}0.07 \\
(10.88 \%)\end{array}$ \\
\hline $\mathrm{F}$ & $\begin{array}{c}0.42 \\
(5.43 \%)\end{array}$ & $\begin{array}{c}0.42 \\
(4.88 \%)\end{array}$ & $\begin{array}{c}3.48 \\
(15.77 \%)\end{array}$ & $\begin{array}{c}0.20 \\
(7.40 \%)\end{array}$ & $\begin{array}{c}0.61 \\
(4.69 \%)\end{array}$ & $\begin{array}{c}-3.99 \\
(-7.86 \%)\end{array}$ & $\begin{array}{c}0.00 \\
(0.00 \%)\end{array}$ \\
\hline
\end{tabular}

$\mathrm{DBH}=$ diameter at breast height, $\mathrm{MOE}$ = modulus of elasticity; scenarios A: selection for each independent trait; B: selection based on DBH, but calculating indirect effect on other correlated traits, C: selection based on volume, but calculating indirect effect on other correlated traits, D: selection based on volume and form, E: selection based on volume and MOE, F: selection based on volume and MOE with the restriction of no change on bark thickness

of trees, in that diameter, height and volume are strongly inter-correlated (Butcher et al. 1996, Whittock et al. 2003, Gonçalves et al. 2005, White et al. 2007, Retief \& Stanger 2009). These mean that bigger trees tend to have thicker bark. However, selection for bigger tree would reduce the bark to volume ratio due to negative genetic correlation between bark ratio and tree volume.

MOE had positive moderate genetic and phenotypic correlations with growth (0.33-0.50) which were similar to Eucalyptus nitens and E. globulus (Blackburn et al. 2014, Hamilton et al. 2017), but with the exception in Eucalyptus urophylla (Wu et al. 2013). This positive correlation is in contrast to most studies in conifer species where high or moderate negative genetic correlations were observed, such as Pinus radiata (Wu et al. 2008), Pseudotsuga menziesii (Johnson \& Gartner 2006) and Picea abies (Chen et al. 2015). The positive correlation between growth and MOE in hardwood, particularly in Melaleuca species indicated that it was possible to select trees for larger stem and higher MOE.

\section{Trends of growth and heritability and effect of thinning}

The increased heritability for growth after the thinning at age 4 showed significant effects of selective thinning which caused considerable reduction of phenotypic variation but slight change in additive genetic variation. Increasing heritability for growth may be caused by normal development of the genetic parameter with time and/or selective thinning (Franklin 1979). Effect of selective thinning on heritability were reported in E. urophylla (Kien et al. 2009), P. radiata (Wu et al. 2007) and P. sylvestris (Hannrup et al. 1998). Selective thinning produced higher heritability than unthinned progeny trial. Commercial thinning inflates heritability estimates of growth (DBH), but had less impact on heritability of wood quality traits (Wu et al. 2007).

\section{Age-age correlation}

Age-age genetic correlations for $\mathrm{DBH}$ and height were strong between age 7 and earlier ages except for ages 1 and 2. DBH had strong correlation relative to height at all ages except for age 1. Therefore, early selection for growth of M. cajuputi based on DBH alone may be sufficient and could reduce costs of multiple early measurements.

\section{Selection response}

The positive genetic correlation between growth, stem form, MOE and adverse correlation between these traits and bark ratio are a considerable 
advantage for simultaneous improvement of multiple traits in advanced breeding programmes of M. cajuputi. However, deciding a breeding selection scenario is dependent on the use purpose of Melaleuca wood. As observed, selection based on volume and MOE would result in an increase in MOE (6\%) which was higher than selection based on volume (1\%) or DBH alone $(4 \%)$.

\section{CONCLUSIONS}

This study observed increased heritability for growth traits with tree age and also as a consequence of selective thinning. Such thinning reduced phenotypic variation but had little effect on genetic variation. The age-age genetic correlations for growth traits increased with time and was higher than 0.77 from age 4 . Optimal selection age for a 7-year rotation of M. cajuputi based on DBH was 4 years. Positive genetic correlations between growth traits and MOE indicated that simultaneous improvement of growth and stiffness were possible in $M$. cajuputi. Negative genetic correlation between tree volume and bark ratio meant that selection for bigger tree would reduce bark to volume ratio, which was favourable for sawn timber production. However, no change in bark thickness can reduce genetic gain for volume. Therefore, selection for volume and MOE simultaneously would be the best strategy for $M$. cajuputi breeding selection for production of sawn timber.

\section{ACKNOWLEDGMENTS}

We would like to thank Fries A, Chen ZQ, Harwood C and Nguyen DK for their assistance. We are very grateful to the Forest Science Institute of South Vietnam, especially on the management of the study site by Pham TD. Hong NTH received PhD scholarship from the 'The Key Program of Biotechnology Development and Application in Agriculture and Rural Development' of the Vietnamese Government.

\section{REFERENCES}

BAN DV. 2002. Some wood characteristics of Melaleuca leucadendra, M. cajuputi, $M$ viridiflora and potential uses of their wood. Vietnamese Information on Forest Science and Technology 2: 38-44.

Blackburn D, Hamilton M, Williams D, Harwood C \& Potts B. 2014. Acoustic wave velocity as a selection trait in Eucalyptus nitens. Forests 5: 744-62.
Bradbury GJ, Potts BM \& Beadle CL. 2011. Genetic and environmental variation in wood properties of Acacia melanoxylon. Annals of Forest Science 68: 1363-1373.

Brophy JJ, Craven LA \& Doran JC. 2013. Melaleucas: Their Botany, Essential Oils and Uses. ACIAR Monograph No. 156. Australian Centre for International Agricultural Research, Canberra.

Butcher PA, Matheson AC \& Slee MU. 1996. Potential for genetic improvement of oil production in Melaleuca alternifolia and M. linariifolia. New Forests 11: 31-51.

Graven LA \& Barlow BA. 1997. New taxa and new combinations in Melaleuca (Myrtaceae). Novon 7: 113-119. doi: 10.2307/3392182.

Chen ZQ, Karlsson B, Lundevist SO, García-Gil MR, Olsson L \& WU HX. 2015. Estimating solid wood properties using Pilodyn and acoustic velocity on standing trees of Norway spruce. Annals of Forest Science 72: 499-508.

Chuong H, Doran JC, Pinyopusarerk K \& Harwood CE. 1996. Variation in growth and survival of Melaleuca species in the Mekong Delta of Vietnam. Pp 31-36 in Tree Improvement for Sustainable Tropical Forestry. QFRI-IUFRO Conference. 27 October-1 November 1996, Caloundra.

Doran JC, Rimbawanto A, Gunn BV \& Nirsatmanto A. 1998. Breeding plan for Melaleuca cajuputi subsp. cajuputi in Indonesia. Technical Report No. 98/178. CSIRO Forestry and Forest Products, Canberra.

Doran JC \& Turnbull JW. 1997. Australian Trees and Shrubs: Species for Land Rehabilitation and Farm Planting. ACIAR, Canberra.

FALCONER DS \& MACKAY TFC. 1996. Introduction to Quantitative Genetics. Fourth edition. Longmans Green, Harlow.

FrANKLIN EC. 1979. Model relating levels of genetic variance to stand development of four North American conifers. Silvae Genetica 28: 207-212.

Gonçalves PDS, Moraes MLTD, Bortoletto N, Costa RBD \& Gonçalves ECP. 2005. Genetic variation in growth traits and yield of rubber trees (Hevea brasiliensis) growing in the Brazilian state of São Paulo. Genetics and Molecular Biology 28: 765-772.

Grabianowski M, Manley B \& Walker JCF. 2006. Acoustic measurements on standing trees, logs and green lumber. Wood Science and Technology 40: 205-216.

Hamilton MG, Freeman JS, Blackburn DP, Downes GM, Pilbeam DJ \& Potts BM. 2017. Independent lines of evidence of a genetic relationship between acoustic wave velocity and kraft pulp yield in Eucalyptus globulus. Annals of Forest Science 74: 17. https://doi. org/10.1007/s13595-017-0617-2.

Hannrup B, Wilhelmsson L \& Danell O. 1998. Time trends for genetic parameters of wood density and growth traits in Pinus sylvestris L. Silvae Genetica 47: 214-219.

Hong NTH, Nguyen NT, Thach PC \& Dat KT. 2010. Trial of Melaleuca species/provenances in the Mekong delta. Pp 31-41 in Dung PT (ed) Melaleuca. Agricultural Publishing House, Ho Chi Minh.

Isik F, Holland J \& Maltecca C. 2017. Genetic Data Analysis for Plant and Animal Breeding. Springer International Publishing AG, Cham.

JAYAWICKRAMA KJS. 2001. Breeding radiata pine for wood stiffness: review and analysis. Australian Forestry 64: $51-56$.

JOHNSON GR \& GARTNER BL. 2006. Genetic variation in basic density and modulus of elasticity of coastal Douglasfir. Tree Genetics and Genomes 3: 25-33. 
Junji M. 1999. Possibility of development for uses of Melaleuca cajuputi wood. Pp 185-191 in The Seminar on Afforestation Technology Development on Acid Sulphate Soils in the Mekong Delta. 20-22 December 1999, Ho Chi Minh.

KARTIKAWATI NK. 2016. Fertility variation of Melaleuca cajuputi subsp. cajuputi and its implication in seed orchard management. Indonesian Journal of Forestry Research 3: 83-94.

Kartikawati NK, Naiem M, Hardiyanto EB \& Rimbawanto A. 2013. Improvement of seed orchard management based on mating system of cajuputi trees. Indonesian Journal of Biotechnology 18: 26-35.

Kha LD, Chuong H, Nguyen NT \& Pinyopusarerk K. 1999. Selection of Melaleuca species for planting in Mekong delta. Pp 255-266 in The Seminar on Afforestation Technology Development on Acid Sulphate Soils in the Mekong Delta. 20-22 December 1999, Ho Chi Minh.

Kien ND, Jansson G, Harwood C \& Thinh HH. 2009. Genetic control of growth and form in Eucalyptus urophylla in northern Vietnam. Journal of Tropical Forest Science 21: 50-65.

KLeINN C. 2007. Lecture Notes for the Teaching Module Forest Inventory. Georg-August-Universität Göttingen, Lower Saxony.

Nuyim T. 2001. Potentiality of Melaleuca cajuputi Powell cultivation to develop for economic plantation purpose. Royal Forest Department, Chatuchak.

Pinypusarerk K \& Doran JC. 1999. Genetic improvement of Melaleuca leucadendra in Vietnam. Pp 163-177 in The Seminar on Afforestation Technology Development on Acid Sulphate Soils in the Mekong Delta. 20-22 December 1999, Ho Chi Minh.

Retief ECL \& Stanger TK. 2009. Genetic control of wood density and bark thickness, and their correlations with diameter, in pure and hybrid populations of Eucalyptus grandis and E. urophylla in South Africa. Southern Forests: A Journal of Forest Science 71: 147-153.

Susanto M, Doran J, Arnold R \& Rimbawanto A. 2003. Genetic variation in growth and oil characteristics of Melaleuca cajuputi subsp. cajuputi and potential for genetic improvement. Journal of Tropical Forest Science 15: 469-82.

Tran DB, Dargusch P, Moss P \& Hoang TV. 2013. An assessment of potential responses of Melaleuca genus to global climate change. Mitigation and Adaptation Strategies for Global Change 18: 851-67.
TRUNG NQ. 2008. Melaleuca timber-resource potential and its current use in Kien Giang Province. Technical report 04E1208TRUNG for GTZ Kien Giang Biosphere Reserve Project. Deutsche Gesellschaft fuer Technische Zusammenarbeit $\mathrm{GmbH}$, Bonn.

Wahyudi I, Ishiguri F, Aiso H et Al. 2014. Anatomical characteristics and wood properties of Melaleuca leucadendron naturally growing in secondary forest in Indonesia. Australian Forestry 77: 168-72.

Van TK, Rayachhetry MB, Center TD. 2000. Estimating above-ground biomass of Melaleuca quinquenervia in Florida. Journal of Aquatic Plant Management 38: 62-67.

White TL, Adams WT \& Neale DB. 2007. Quantitative genetics-polygenic traits, heritabilities and genetic correlations. Pp 113-147 in Forest Genetics. CABI Publishing, Cambridge.

Whittock SP, Apiolaza la, Kelly CM \& Potts BM. 2003. Genetic control of coppice and lignotuber development in Eucalyptus globulus. Australian Journal of Botany 51: 57-67.

Wu HX, Ivković M, Gapare WJ, Matheson AC, Baltunis BS, Powell MB, and Mcrae TA. 2008. Breeding for wood quality and profit in radiata pine: a review of genetic parameters and implication for breeding and deployment. New Zealand Journal of Forest Science 38: 56-87.

Wu HX, Powell MB, Yang JL, Ivković M \& Mcrae TA. 2007. Efficiency of early selection for rotation-aged wood quality traits in radiata pine. Annals of Forest Science 64: $1-9$.

Wu S, Xu J, Li G ET AL. 2013. Genetic variation and genetic gain in growth traits, stem-branch characteristics and wood properties and their relationships to Eucalyptus urophylla clones. Silvae Genetica 62: 218-231.

Yamanoshita T, Kawazoe T, Tange T et AL. 1999. Adaptation of Melaleuca cajuputi to flooded conditions in tropical peat swamps. Pp 469-472 in Proceedings of International Symposium: Can Biological Production Harmonize With Environment? Reports From Research Sites in Asia-Major Element. 19-20 October 1999, Tokyo.

Zobel BJ \& Jett JB. 1995. Genetics of Wood Production. Springer-Verlag, New York. 